\title{
Correlations between the concepts of disinformation and Fogg's Behavior Model
}

\author{
Correlações entre os conceitos de desinformação \\ e o Modelo Comportamental de Fogg
}

\author{
Enrique MURIEL-TORRADO1 (D) 0000-0003-0969-9500 \\ Danielle Borges PEREIRA ${ }^{1}$ (D) 0000-0003-3281-9654
}

\begin{abstract}
As connectivity and interactions on the internet and social media grew easier, it made it possible for any individual to create and disseminate information or news as desired, which resulted in the growth of disinformation, leading to questions of how human beings can be manipulated by false information. The main objective of this research is to correlate the concepts of false news and misinformation with Fogg's Behavior Model. By considering the correlation between the definitions and concepts applied by the selected bodies and institutions and the factors of Fogg's Behavior Model, we conclude that all the definitions have aspects correlated with the factors raised by Fogg for the persuasion toward a desired behavior, thus showing how false information can be used to manipulate individuals who are likely to believe in a certain topic, those who do not have knowledge of verifiability procedures for misinformation or those who have already been affected by informational fatigue.
\end{abstract}

Keywords: Disinformation. Fake news. False information. Fogg's behavior model.

\section{Resumo}

A facilidade de conectividade e interatividade dos seres humanos com a Internete as mídias sociais fez com que qualquer indivíduo possa criar e divulgar a informação ou notícia desejada por estes meios de comunicação e isso decorreu o crescimento da desinformação, levando questões de como os seres humanos podem ser manipulados pelas informações falsas. Sendo assim, esta pesquisa tem por objetivo principal correlacionar os conceitos de notícias falsas e desinformação com o Modelo de Comportamento de Fogg. A partir da correlação das definições e conceitos aplicados pelos órgãos e instituições selecionadas e os fatores do Modelo de Comportamento de Fogg. Conclui-se que todas as definições possuem aspectos correlacionados com os fatores levantados por Fogg para a persuasão de um comportamento desejado, mostrando assim como as informações falsas podem ser utilizadas para manipular os indivíduos que possuem tendências a acreditar em determinado assunto, aos que não possuem conhecimento de verificabilidade de desinformação ou aos que já foram afetados pelo cansaço informacional.

Palavras-chave: Desinformação. Notícias falsas. Informação Falsa. Modelo de comportamento de Fogg.

\footnotetext{
1 Universidade Federal de Santa Catarina, Centro de Ciências da Educação, Programa de Pós-Graduação em Ciência da Informação. Campus Professor João David Ferreira Lima, s/n., Trindade, 88040-900, Florianópolis, SC, Brasil. Correspondência para/Correspondence to: E. MURIEL-TORRADO. E-mail: <enrique. muriel@ufsc.br>.

Support: Coordenação de Aperfeiçoamento de Pessoal de Nível Superior - Programa de Demanda Social (Process n॰ 88882.438268/2019-01).

Received on May 14, 2020, final version resubmitted on August 5, 2020 and approved on October 9, 2020.
}

Como citar este artigo/How to cite this article

Muriel-Torrado, E; Pereira, D. B. Correlations between the concepts of disinformation and Fogg's Behavior Model. Transinformação, v. 32, e200026, 2020. https://doi.org/10.1590/2318-0889202032e200026 


\section{Introduction}

Information can be considered a very powerful tool and its negative use can bring social and economic damage to a nation (Rodrigues, 2011). Essential for the development of human life, information is present in all its stages, from the beginning of our cognitive development as children to the selection and choice of a profession in adulthood (Yuexiao, 1988). Thus, we can affirm that people consume information daily, sometimes as searchers and users in a purposeful way, but many times without awareness of the cluster of information that is received (and often passed on) in our lives (Cooke, 2018).

Bauman calls the period in which we live "liquid modernity". Our productions and relations are quicker and more fluent, our needs and desires short term they are quickly resolved or satisfied. Differently from what happened decades ago, when we consumed only what was necessary to survive, we have now built a new identity based on the precepts of capitalism and the search for social acceptance, and we enjoy greater freedom of action and expression, of being able to create and develop projects and information at any time, and to thrive on that freedom (Bauman, 2001).

Information and news are heading toward precisely this state of liquidity, with easier processes of publication and wider connectivity through social media. They are also becoming malleable and replaceable, as every week or even every day a new focus of news comes up, when, most of the time, we did not even have time to recover from the information transmitted by the news on the previous week. These processes generate an overload scenario for the population, also causing anxiety and fatigue, which in turn can begin the dissemination of disinformation (D’Ancona, 2018).

Society has been reformulated over the years and this is partially due to the fact that individuals constantly hold demonstrations in order to defend their own or their groups'opinions, and also to their relation with activisms that they consider correct. Nowadays, this occurs on a larger scale, which is partly due to the creation of laws granting the right to freedom of expression. However, these recent phenomena have been occurring primarily in emotional ways, with the struggles no longer laid out in terms of relevant ideas and criticisms, but for individualistic issues, leading to doubt and the distrust of science, studies, and research carried out around the world (D'Ancona, 2018). This political and intellectual fight can be related to false information, especially with its current popularity; after all, false news and the post-truth grew in knowledge and reach since the presidential election of the United States of America in 2016 (Alcott; Gentzkow, 2017).

We have always been surrounded by false information and news, but for the most part it was taken as jokes or related to scams. As the perception of the junction of disinformation and politics or other means that affect the citizens of a society grew, fake news started to be part of people's daily lives, as it is considerably easy to manipulate a human's desired behavior, especially when the behavior has ideological characteristics and involves issues that individuals already have a tendency to believe in (D'Ancona, 2018).

What our ancestors lacked of information, either from disinterest or due to social, economic, or physical inequalities, we currently have in excess mainly through the media, even though the aforementioned inequalities still exist (Masi, 2019). It is thus necessary that information is created and disseminated correctly and that its senders can make good use of it in critical and conscious ways, distinguishing relevant and superfluous messages, so that the population does not become socially and personally unbalanced (Barreto, 1994; Masi, 2019).

The creation of computers and the modeling of machines increased the demand for studies on human cognition, especially those related to the extensive amount of information available nowadays. Therefore, the interest in research that aims at understanding and learning the way people think and perceive the world around them is more and more relevant (Neves, 2006). 
The connection between the subjects addressed above explains the emergence of the objective of this study, which seeks to identify and cover the existing correlations between human behavior in the digital environment with the Fogg's Behavior Model and the paradigm of the definitions of false information, with the purpose of addressing the growing disinformation and manipulation of individuals. Fogg's Behavior Model includes three elements (Motivation, Ability and Trigger) that have factors and characteristics which can be used to persuade the desired behavior of citizens individually or in groups (Fogg, 2009). Thus, this paper's objective is to identify if there is a correlation between the conception of fake news and misinformation and the Fogg's Behavior Model. The research was done in two parts: (a) first, we identified five notions of fake news or misinformation operating in institutions or agencies that work with matters of information, education, science, and/or society; and (b) then, we correlated the conceptions of fake news or disinformation comparing the definitions with the Fogg's Behavior Model.

\section{Information and disinformation}

Information has always been present in the life of human beings and as part of their development. The greatest growth in information and its forms of registration and organization come with the creation and popularization of the Gutenberg press in 1450, making it progressively easier to create and store information. From then on, the production of news grew and so did the population's skepticism, which led to more research and studies so that knowledge and true information could be socially disseminated (Burke, 2003). In this context, Burke (2003) states that the large amount of information produced, mainly, with the arrival of the Internet and social media prompted a "knowledge crisis" where people live in exaggerated contact with information that is not always useful or true and this ends up confusing the population that currently does not know what information, news, agency, or professional to trust.

Castells (2003) recognizes the negative characteristics arising from the in-formation explosion, but states that the Technology Revolution (the period of the emergence of the Internet, as he himself named it) brought information and knowledge to society within a new cycle of development and innovation, where not all individuals have full access. After the Technology Revolution, Castells (2003) also analyses what he calls the Information Technology Revolution, which expanded the ways of living socially and culturally through changes in the behavior of individuals and their means of interaction and communication, making them dependent on these new modes.

One of the first writings related to information in the context of Information Science was carried out by Borko in 1968. With the purpose of explaining what In-formation Science is, Borko's work was later considered the fundamental source of this area. For Borko (1968), Information Science is a discipline that investigates informational properties and behavior, information flows and processing, aiming at improving its access and use, that is, storage and ideal recovery. It is important to remember that Borko (1968) wrote about this subject during the Cold War and the post-World War II periods, which enables us to see his significant interest in exposing the study of information in a mechanical and technical way. It is noteworthy that he deals only with the study of flows, procedures, and operations, based on the mathematical theory of communication and systemic theory.

By relating the dissemination of misinformation with Information Science, we are able to bring the concepts and classifications of information addressed by Buckland and Capurro. Over the years, the concepts built and employed by several authors regarding Information Science and its object of study - "information" - have changed, the field has been reconstituted in more countries, and each location contributed significantly to the aspects of this new field of study.

Buckland (1991) identifies information with three main uses of the word: information-as-process deals with the act of informing; information-as-knowledge that is perceived in information-as-process, which is acquired knowledge and information-as-thing designates objects, such as data and documents, about which they can provide information that can be transformed into acquired. Another scholar in the field defines information by 
dividing it into the three epistemological paradigms prevalent in Information Science: the physical (the physical object of a signal and the transmission of a message, must have informative value); the cognitive (related to the search for knowledge due to a gap or need); and the social (which treats information as something linked to the user) (Capurro, 2003).

After raising some concepts and paths taken by information, it is important to contextualize the route of false information. For D'Ancona (2018), false information becomes more intensive after the Industrial Revolution and the media changes that lead to the Digital Revolution, when the forms of communication and interaction between individuals through social media become much more easy. This leads to the proliferation of disinformation, which today is a State problem that involves the social, cultural, and cognitive aspects of society.

The current concern and the urgency to solve or reduce the amount of disinformation is partly because of the modification of human behavior, as some individuals' daily activities, such as reading and interpretation, lost part of their critical edges, causing mechanical behaviors in relation to information and further propagating the wave of 'informational pollution', as called by Leite and Matos (2017). When related to events or happenings, information used to be practically synonymous with veracity, but currently, with many environments and tools capable of replicating information in the most diverse ways while using different sources of information at high speed, it is increasingly difficult and complex for people to verify the veracity of the information, especially if it is exposed on the Internet or published on social media (Leite; Matos, 2017).

The excess of information overloads the cognitive system of human beings and ends up precluding its main objective, which is to inform and make people search for knowledge. Now the information is being treated both by the sender and the receiver as a product, whether to advertise goods or services, to leverage an individual's social status, or to manipulate a society (Leite; Matos, 2017).

In addition to considering the cognitive process of human beings as influencing the dissemination of disinformation, the emotional or affective components contained in the false information can be framed in this sense as well. By understanding these components deeply, it is possible to understand how and why the disinformation is spread so quickly. According to Cooke (2018), a striking feature of users who consume false information is that they pass on this information because it agrees with or confirms their ideologies or beliefs, and are able to influence individuals emotionally. The cognitive and emotional dimensions of individuals are related during the processes of collecting and selecting information from social media users, which that can influence their behavior regarding the use of information. For example, filter bubbles or social bubbles can cause only certain pieces of information to reach the user; information overload that causes fatigue, as well as the lack of veracity of information and satisfaction of information, which can drive the user not to research about it and just believe what is informed (Cooke, 2018).

We live in a world with unprecedented access to information and scientific knowledge. To a large extent, we can credit the creation and wide spreading of the Internet for this achievement. In this context, Silva (2020) raises questions about the fact that a portion of society chooses to believe in information that is not scientifically verifiable and even defy previously proven historical events as non-existent. The author brings an observation on the context that can justify such actions:

Faced with a world full of uncertainties and the constant questioning of the supposed normality, it is not surprising that those uncomfortable with the apparent discontent leave in search for promises, certainties, and guarantees, even if manufactured and false. And nothing is more comfortable than reading just what we want to believe (Silva, 2020, p. 51, our translation)².

\footnotetext{
2 In original: Diante de um mundo repleto de incertezas e do questionamento constante da suposta normalidade, não é de se estranhar que aqueles desconfortáveis com o aparente mal-estar saiam em busca de promessas, certezas e de garantias, ainda que fabricadas e mentirosas. E nada mais confortável do que ler apenas o que queremos acreditar (Silva, 2020, p. 51).
} 
A factor that makes false information viral is the whereabouts these pieces circulate in: at the beginning, they are usually presented to people who have a propensity to believe them, people who have preconceptions equal to or similar to those falsely reported in certain news, which cause them to question themselves less about the pieces' veracity. That is why the proliferation of disinformation becomes so dangerous for people and society as a whole (Silva, 2020).

Lying, as well as disinformation, has existed for a long time. However, just as the access to information in past centuries was precarious, many times even what was considered disinformation did not come to be a very relevant factor in our society. Nowadays, with the information explosion and the popularization of the Internet and social media together with the possibility of interaction in these media, false information gained other proportions when compared to a few centuries ago (Alcott; Gentzkow, 2017). In this sense, to understand what goes on in the minds of individuals when formulating, creating, or disseminating false information, it is necessary to analyze human behavior, especially in the digital environments where all of this occurs in a more accelerated and disseminated way. One should thus take both these factors into account in order to better understand how human beings' development and relationships with each other and with current technologies can contribute to the dissemination of disinformation (Moutinho; Roazzi, 2010).

\section{Fogg's Behavior Model}

Fogg's Behavior Model is a persuasive technology developed by Brian Jeffrey Fogg in order to define patterns of attitudes and behaviors designed to influence in digital environments. The model includes characteristics of human psychology and behavioral orientations, and its main focus is to better understand the changes in human behavior in the media and in digital technologies, constituting a systematic way of understanding these phenomena (Fogg, 2009).

Fogg's Behavior Model classifies within three elements (Motivation, Ability, and Trigger) for the persuasion toward desired behavior. Each element is divided into sub-elements: Motivation is managed by feeling and includes Pleasure/Pain, Hope/Fear and Social Acceptance/Rejection; Ability is understood as the easiness or difficulty to perform a behavior and it includes Time, Money, Physical Effort, Brain Cycles, Social Deviation; and Non-Routine; finally, the Trigger element is subject to the stimulus of which are performed by Spark, Facilitator, and Signal (Fogg, 2009).

The relationship represented in the Fogg's Behavior Model can be used in different ways in order to identify and understand the behavior of either humans or machines. In this research, the correlation of Fogg's Behavior Model with the definitions or concepts formulated by a group of selected bodies and institutions will be analyzed through these elements. In this segment, the greater the number of elements and their sub-elements used in a definition, the greater the chances of achieving the desired behavior. For this to occur, there must be at least one sub-element of each element.

In order to better understand the factors and elements developed by Fogg, assume that we are faced with a publication that we want to share and that this brings us a motivation, whether positive or negative, that is easy and quick to carry out the sharing and to have a trigger already pre-conceived by individuals, this increases chance of sharing increases much more than when none of these elements are used. This becomes even more serious when have information that influences the perception of citizens and has consequences for democracy, as occurs in cases of dissemination of disinformation, especially those involved in matters of government and public health.

To effectively carry out the modulation of behavior, it is essential that the Trigger is intense. The behavior can have more Ability or Motivation, the important thing is that they (Ability and Motivation) are predominant to reach the target behavior (Fogg, 2009). Therefore, Motivation and Ability are essential for the achievement of the desired 
behavior, as people with more motivations and skills related to a certain subject are more likely to share information or news, often without verifying the facts (Fogg, 2009). However, these elements do not need to be on the same frequency - a user can have a lot of Motivation and little Ability and perform a behavior similar to the one of a user with little Motivation and low Ability. Is it important that they are connected, though, even if lately high Ability is becoming more important than high Motivation as it makes it easier to carry out a behavior, while motivation can be influential in the background and even work its way through a Trigger (Fogg, 2009). The most important element for the realization of the desired behavior is definitely the Trigger, as long as it is properly constructed and right after the desired behavior is defined. In order to have everything come out correctly, it is important to study and analyze the target (user) and the targeted behavior, so that the best forms and sub-elements of Fogg's model are chosen and applied.

The element of Motivation has three sub-elements and it is responsible for propelling the user to perform a desired behavior. Pleasure/Pain is adaptable and considered a primitive and dishonest way of influencing a desired behavior. Hope/Fear corresponds to the anticipation of something good or bad and is considered the most ethical motivator. Finally, Social Acceptance/Rejection represents the inclination of human beings to look for social acceptance in digital environments and therefore they can perform certain behaviors for this purpose or in order not to be excluded (Fogg, 2009). Examples regarding the sub-elements of Motivation are as follows. Pleasure/Pain involves carrying out any activity that gives you pleasure, such as eating your favorite food, or the pain arising from an inflicted violence that consequently generates the need for protection. Hope/Fear are illustrated, for instance, by the hope of doing something productive in your professional career or the fear of not being able to accomplish something that you want. Finally, as examples of the Social Acceptance/Rejection sub-element, we can mention the desire for social acceptance in a group of messages or on social media and interaction as a way to prevent social rejection (Fogg, 2009).

When framed in a context of creation and dissemination of false information, these examples correspond to the characteristics responsible for misinformation. In the context of creating "fake news", most of the time the topics addressed are related to a person's own desires, bringing out feelings of hope or fear that the news are true. Sometimes, individuals share these news in order to be socially accepted or, in some cases, they are afraid of being rejected for disagreeing with other people and/or not believing in the false information.

The element of Ability corresponds to how easy and simple performing a behavior is. The easier and simpler, the more likely the user will be to perform it. This element has six sub-elements and the greater the amount of sub-elements used, the better the effectiveness of persuasion will be (Fogg, 2009). The first sub-element is Time: the less time it takes the user to perform the behavior, the easier it is to perform it. The sub-element Money deals with behavior that does not require financial resources, making it easier to accomplish; Physical Effort must be unnecessary if it is desired to facilitate a target behavior. Brain Cycles respond for the ability of thinking. If the behavior does not require critical or what is considered a lot of thinking, it will be more easily accomplished. Social Deviation represents that the desired behavior cannot go against the rules if it is to be considered normal and be socially accepted. Finally, the Non-Routine sub-element deals with a target behavior that does not escape the usual routine of users, otherwise it will not be easily performed (Fogg, 2009).

Again, Ability corresponds to sub-elements that represent simplicity and easiness when using the Internet and social media. Hence, Time, Money, Physical Effort, Brain Cycles, Social Deviation, and Non-Routine are factors that facilitate the life of users who will accomplish the desired behavior, as the following examples of optimizing these sub-elements demonstrate. As examples of Time, we can mention online purchases or register on a website that does not need to fill in much information (Fogg, 2009). As for Money, an example is the use of free websites and with different functions instead of using similar ones that are paid. Physical Effort corresponds to the act of not having to travel to perform a desired behavior, as when making purchases over the Internet either in a bookstore or in an online supermarket instead of going to these places physically (Fogg, 2009). Cerebral Cycles are reflected, for 
example, in choosing a story to read with five pages instead of one with 30 pages on the same subject or in reading the news only by the headlines rather than in full. Social Deviation is consistent with going to work in pajamas in an environment with a formal dress code. Non-routine represents the act of always doing the same things and not leaving the routine, as when one goes to work and returns home on the same route (Fogg, 2009).

Correlating these examples with misinformation concerns the construction of the false information that will be disseminated, most of which will display the characteristics of easy access and language, little information and short texts, in a way that does not totally deviate from the social norms accepted by these individuals. The third element of Fogg's model is the Trigger. When applied, Triggers are intended to lead to the immediate realization of the expected behavior. Triggers can be momentary and are not always the same for users or desired behaviors. It has three sub-elements: the Spark serves to increase the sub-elements of Motivation, and it should be used when the person shows little or no motivation; the Facilitator simplifies or makes behavior likely to happen, and it is used when a person is motivated but has little or no ability to perform the desired behavior; finally, the Sign works to remind the individual that a certain type of behavior must be performed, and it must be used along with some level of Motivation and Ability to work (Fogg, 2009).

Such sub-elements of the Trigger element have slightly different characteristics from the sub-elements of Motivation and Ability, as they do not aim to motivate a desired behavior or make this behavior easier to accomplish, but to share a message either in the form of a reminder or as a further fact of encouragement for pre-existing motivation and skills (Fogg, 2009). A video or message that inspires hope can be considered an example of Spark, while the update of an antivirus software by a user who is afraid of getting viruses on their computer is a Facilitator example; finally, using an application that reminds you to drink water can be characterized as a Signal (Fogg, 2009). All sub-elements of Trigger can be used during the dissemination of misinformation, either as encouragement to share the pieces more by bringing hope or fear to the user (Spark) or by making it easy and practical to share it without verification (Facilitator), or because the user keeps receiving so many messages related to a certain piece of false information that they end up believing its veracity and disseminating it to other users on social media (Signal). The elements presented are a way of understanding certain human behaviors and explaining the reasons why some people or groups perform certain activities or functions. They also help understand the work done by digital developers and the various mechanisms and tools available to systematize and influence behaviors that involve human feelings (Fogg, 2009).

\section{Methodological Procedures}

The present study is an exploratory, documentary, and qualitative research that aims to identify existing correlations between the elements and factors of Fogg's Behavior Model and the concepts and definitions regarding the disinformation framework formulated by organs and institutions involved in the growth of society, science, and education, and which are related to the dissemination of information to all citizens. The institutions are: the United Nations Educational, Scientific, and Cultural Organization (UNESCO), the European Commission, the Oxford Dictionary, The World Economy Forum, and the news agency Reuters.

This study was carried out in two stages. The first stage dealt with the identification of official bodies or institutions related to issues of information, education, science, and society. We also sought to identify institutions that are relevant actors when dealing with topics such as fake news and disinformation. The United Nations Educational, Scientific, and Cultural Organization was selected for having developed a manual for journalism which aims to teach journalists about disinformation, not accepting the use of the term "false news" (stating that if it is news it should not be false, since all news is implicitly true) and constructed the definitions of Disinformation, Misinformation, and Misleading. The European Commission was chosen for being an institution in defense of the interests and rights of the European Union and whose definitions regarding disinformation need to be analyzed. 
The Oxford Dictionary was selected because it is a world-renowned dictionary and for having declared words like "Post-truth" relevant in 2016, which is related to the terms of disinformation and fake news. The World Economy Forum is an economic organization that brings businessmen and politicians together to discuss issues emerging in society. That is why it was selected for the analysis of its definitions regarding disinformation, as the growth of false information is currently an urgent matter in our society. Finally, Reuters was selected because it is the largest international news agency in the world, so the concepts of disinformation or fake news it employs are important for the analysis of the areas of journalism and news.

After the identification and selection of organizations and institutions that worked with concepts or definitions of disinformation and fake news, we collected the concepts themselves. The second stage of the research started, trying to correlate the concepts and definitions of each institution with the three factors of the Fogg's behavior model and its elements. The correlation of Fogg's factors and elements with the concepts employed by the selected institutions was carried out with readings, text interpretation, and connection between the terms presented by Fogg to define his factors and the terms presented in the institutions' definitions. We thus carried out a reading of the selected concepts, later relating them with some elements of Fogg's Behavior Model.

\section{Analysis and Results}

After the burst of information, the growing popularization of social media, and the production of published information, it can be shared in any way and by any individual influenced by it. This way, the quality, veracity, and credibility of information nowadays is at best doubtful, as is the respect and confidence socially enjoyed by information and communication professionals (Ireton; Posetti, 2018).

In this sense, Unesco has developed definitions regarding disinformation. It has also organized and classified the existing types of false information. It does not include the term "fake news", as it considers that false news should not be named "news", since every piece of news must be true (Ireton; Posetti, 2018). United Nations Educational, Scientific, and Cultural Organization definitions of false information (Ireton; Posetti, 2018) are divided into three items: (a) Disinformation: Information that is false and deliberately created to harm a person, a social group, an organization, or a country; (b) Misinformation: Information that is false but not intended to cause harm; and (c) Misleading Information: Reality-based information used to harm a person, social group, organization, or country. A simplified definition of "fake news" is also granted by Unesco, indicating "[...] intentionally lying content that is launched on fake websites or social networks to harm a person or a group. United Nations Educational, Scientific, and Cultural Organization prefers to call them disinformation campaigns." (United..., 2019, p. 3, our translation) $)^{3}$.

The European Commission (2019, p. 1) has defined disinformation as "[...] verifiable, false or misleading information created, presented and disseminated for economic gain or intentionally misleading the public". The definition added that disinformation can be used to destabilize democracies by removing the credibility and trust of organs and institutions and causing damage to society, as it can influence the discrediting of public health, politics, security, and the environment. Furthermore, it can also render the rights of citizen to have access to true information and freedom of expression unfeasible (European Commission, 2019).

In the Oxford Dictionary, the definitions of the terms "fake news", "disinformation", and "post-truth" basically deal with the spreading of fake news and the power that individuals' beliefs can bring about as to whether they believe false information or not. Such definitions are as follows:

\footnotetext{
3 In original: [...] intencionalmente mentirosos que são lançados em sites falsos ou redes sociais para prejudicar uma pessoa ou um grupo. A Unesco prefere chamá-las de campanhas de desinformação (United..., 2019, p. 3).
} 
- Fake news: false reports of events written and read on websites. Many of us seem unable to distinguish fake news from verified sources. Fake news create significant public confusion about current events (Oxford..., 2020a).

- Misinformation: the act of giving wrong information about something and the wrong piece of information that is given. A campaign of misinformation. Attitudes based on misinformation (Oxford..., 2020b).

- Post-truth: relating to circumstances in which people respond more to feelings and beliefs than to facts. In this era of post-truth politics, it is easy to cherry-pick data and reach any conclusion you like (Oxford..., 2020c).

The World Economy Forum (Charlton, 2019, p. 2), a non-profit organization, state that fake news "can be as slippery to define as it is to pin down. Stories may be factually inaccurate and deliberately published to underscore a certain viewpoint or drive lots of visitors to a website, or they could be partially true but exaggerated or not fully fact-checked before publication." For Reuters (Nielsen; Graves, 2017, p. 1), a British news agency that is one of the largest international news agencies in the world, fake news are defined from the viewpoint of its readers, as in: "[...] fake news is only in part about fabricated news reports narrowly defined, and much more about a wider discontent with the information landscape - including news media and politicians as well as platform companies".

In order to demonstrate the correlation between the definitions of false information and news with the elements of Fogg's method, in addition to explaining the reasons that lead to this relationship, four tables are presented below. Chart 1 presents the existing correlations of the definitions of the term "fake news" formulated by the Oxford Dictionary, World Economic Forum, and Reuters with the elements of Fogg's Behavior Model. In general, the three elements and their sub-elements are present equally: Ability appears three times with its sub-elements Brain Cycles, Social Deviance, and Time; the Motivation element appears three times with two occurrences for Pleasure/Pain and one occurrence for Social Acceptance/Rejection; finally, the Trigger element appears with its three sub-elements - Spark, Facilitator, and Signal.

The correlation of the Oxford Dictionary's concept of fake news with the sub-elements of the element Ability "Brain Cycles" and "Social Deviance" represents that: (1) certain behavior related to false news, whether its production or dissemination, does not require critical thinking and dispenses analyzing its veracity; and (2) talking about false reports and events can be related to "Social Deviance", as its fabrication may need to go against social rules and norms.

The World Economic Forum's definitions exhibit correlations with the three elements. "Pleasure/Pain" and "Social Acceptance/Rejection" (Motivation) occur because the false information is developed through a specific point of view and can raise motivations and emotions of pleasure and/or fear for users who already believe in certain topics. This can also lead the user to be influenced in search of social acceptance. The sub-elements "Time" (Ability) and "Facilitator" (Trigger) correlate with the fake news that are available on websites of easy and simple access and in a short period of time, while "Signal" (Trigger) correlates with places where fake news are generally used as reminders to perform certain behaviors.

Reuters's definition of fake news correlates with the sub-elements "Pleasure/Pain" (Motivation) and with "Spark" (Trigger), representing that a well-formulated piece of false news can lead certain users to share it out of fear or discontent with the false information published. It thus makes them act according to their ideologies and beliefs, and not critically. Together with Motivation, the Trigger present in this definition increases motivation for the person to believe the fake news.

The definition of disinformation was formulated both by Unesco and the European Commission, and their existing correlations with the elements of Fogg correspond to the elements Motivation (Pleasure/Pain) and Trigger (Spark) in the case of Unesco's definitions, and Motivation (Social Acceptance/Rejection), Ability (Time, Money, Brain Cycles, and Social Deviance), and Trigger (Facilitator) in the European Commission's one (Chart 2). 
Chart 1. Correlations of fake news definitions and elements of the Fogg's Behavior Model.

\begin{tabular}{|c|c|c|}
\hline Organizations & Elements of the Fogg's Behavior Model & Correlations: definitions and elements of the Fogg's Behavior Model \\
\hline \multirow[t]{2}{*}{ Oxford Dictionary } & Ability: Brain Cycles & $\begin{array}{l}\text { The definition addresses public confusion, since it is common for the } \\
\text { population to be unable to distinguish true and false news and identify } \\
\text { the truth of news. This factor may be related to the element Ability: Brain } \\
\text { Cycles, as it might require a lot of thinking in order to identify the truth of } \\
\text { Information. }\end{array}$ \\
\hline & Ability: Social Deviance & $\begin{array}{l}\text { Dealing with fake reporting, this concept is about the Social Deviance } \\
\text { Ability, when the dissemination or creation of false information requires } \\
\text { going against the norms and rules. }\end{array}$ \\
\hline \multirow{4}{*}{ World Economic Forum } & $\begin{array}{l}\text { Motivation: Pleasure/Pain and Social } \\
\text { Acceptance/Rejection }\end{array}$ & $\begin{array}{l}\text { This definition informs that false news are published with the intent of } \\
\text { exalting a certain point of view and they correlate to the Pleasure/Pain } \\
\text { Motivation element that may address a determined subject that the users } \\
\text { might possess predisposition to believe in. Also correlating to the Social } \\
\text { Acceptance/Rejection Motivation element, since the users' points of view } \\
\text { are often related to their social behavior and their worries about being } \\
\text { accepted or rejected in a certain social group. }\end{array}$ \\
\hline & Ability:Time & $\begin{array}{l}\text { Fake news direct the users to specific websites. This factor connects to the } \\
\text { Time Ability element because if the user's target behavior saves them time, } \\
\text { this behavior is easier to happen (for example, reading the news with only } \\
\text { a click). }\end{array}$ \\
\hline & Trigger: Facilitator & $\begin{array}{l}\text { This factor relates to the Trigger element. It facilitates user access to fake } \\
\text { news with just one click, knowing that fake news direct users to specific } \\
\text { websites. }\end{array}$ \\
\hline & Trigger: Signal & $\begin{array}{l}\text { This definition can be related to the element Trigger: Signal, as it can serve } \\
\text { as a reminder of a subject from certain point of view, and it becomes more } \\
\text { effective along with some element of motivation and ability. }\end{array}$ \\
\hline \multirow[t]{2}{*}{ Reuters } & Motivation: Pleasure/Pain & $\begin{array}{l}\text { This definition is related to the Motivation element: Pleasure/Pain and } \\
\text { Hope/Fear when it comes to fake news, presenting partially from a } \\
\text { discontent or hope of a specific scenario, generally involved with users' } \\
\text { beliefs and ideologies. For example, when an individual shares false } \\
\text { information through the social media in defense of his or her political } \\
\text { party, corresponds to behavior related to the person's ideology. }\end{array}$ \\
\hline & Trigger: Spark & $\begin{array}{l}\text { The definition of fake news acknowledges news that bring discontentment } \\
\text { from the perspective of a person and a specific scenario, and it also relates } \\
\text { to the Trigger element: Spark. The user that sees fake news already has } \\
\text { involvement with the topics and it only takes a spark for them to become } \\
\text { more likely to believe in such information. }\end{array}$ \\
\hline
\end{tabular}

Source: Based on the study of Fogg (2009); Nielsen; Graves (2017); Charlton (2019); Oxford... (2020a).

For Unesco, correlations exist primarily with "Pleasure/Pain", as it is their definition of Disinformation that it occurs when false information that seeks to affect emotionally certain groups of individuals through their beliefs and ideologies is developed. There are also correlations with "Spark", complementary the pre-established motivation by a misinformation, therefore, only a well-applied spark can make information that is false, in real to individuals who intend to believe. so only a well applied spark can make false information true for individuals who have the intention to believe.

Disinformation as defined by the European Commission employs the characteristics of Fogg's motivational elements regarding "Social Acceptance/Rejection" (Motivation) as it states that disinformation can influence freedom of expression and oppress freedom of opinion, making people feel obligated to share certain pieces of false information in order to fit into groups or not be excluded from them. It also relates with the elements of Ability, as they characterize the choices of individuals in digital environments as preferring: information that is easy to access instead of true information (Brain Cycles); small and easy-to-read pieces of information (Time); and sources of information without financial costs (Money). It also relates to Social Deviation, as these preferences do not result in 
Chart 2. Correlations of disinformation definitions and elements of the Fogg's Behavior Model.

\begin{tabular}{|c|c|c|}
\hline Organizations & Elements of the Fogg's Behavior Model & Correlations: definitions and elements of the Fogg's Behavior Model \\
\hline \multirow[t]{2}{*}{ Unesco } & Motivation: Pleasure/Pain & $\begin{array}{l}\text { The definition of misinformation as a piece of information intended to harm a person or a } \\
\text { group is related to the elements of Motivation by Pleasure/Pain, as it tries to affect certain } \\
\text { groups through their feelings, creating triggers for greater commotion. }\end{array}$ \\
\hline & Trigger: Spark. & $\begin{array}{l}\text { The Trigger as Spark is false information created to harm. When the trigger combined with } \\
\text { the pleasure/pain element is projected, this factor can affect certain people or groups. }\end{array}$ \\
\hline \multirow{5}{*}{$\begin{array}{l}\text { European } \\
\text { Commission }\end{array}$} & $\begin{array}{l}\text { Motivation: Social Acceptance/ } \\
\text { Rejection }\end{array}$ & $\begin{array}{l}\text { These types of information preclude freedom of information and expression. That relates } \\
\text { to element Motivation: Social Acceptance/Rejection. In this element, people are either } \\
\text { ashamed (social rejection) of informing "news" that could be fake or feel the necessity of } \\
\text { informing news, veracious or not, with the intent of being socially accepted. }\end{array}$ \\
\hline & Ability: Brain Cycles & $\begin{array}{l}\text { This definition can be associated with the Ability: Brain Cycles, meaning that the fact } \\
\text { that ordinary people usually don't have the habit of investigating information and news } \\
\text { makes it difficult to access to true information. }\end{array}$ \\
\hline & Ability: Time and Money & $\begin{array}{l}\text { Generally, false information are of easy access and understanding. This factor can be } \\
\text { related to the element Ability: Time and Money, since fake news often bring brief and } \\
\text { free information. }\end{array}$ \\
\hline & Ability: Social Deviance & $\begin{array}{l}\text { By spreading false information that attack democracy, affecting the whole population, } \\
\text { the definition relates to the element Ability: Social Deviance, which requires going against } \\
\text { the norms and rules. }\end{array}$ \\
\hline & Trigger: Facilitator & $\begin{array}{l}\text { The definition of disinformation refers to the easily accessed and comprehended (easy } \\
\text { language) false news that relate to the element Trigger: Facilitator, which aims to facilitate } \\
\text { people's access to information, its understanding, and even dissemination. }\end{array}$ \\
\hline
\end{tabular}

Source: Based on the study of Fogg (2009); Ireton; Posetti (2018); European Commission (2019).

Note: UNESCO: United Nations Educational, Scientific and Cultural Organization.

dishonor to the norms and rules established by society (Social Deviation). The correlation with the Facilitator (Trigger) is seen in the examples above where the information is easily accessible and with a language understandable to all, thus facilitating individuals to perform certain behavior regarding the dissemination of disinformation.

Definitions of misinformation were formulated by Unesco and the Oxford Dictionary, and it was the concept the smallest number of correlations in this work, occurring only with Motivation-Social Acceptance/Rejection, in Unesco's case, and Ability-Social Deviance in the case of the Oxford Dictionary (Chart 3). It Misinformation includes false information that is created not to harm but that is disseminated by individuals who seek social acceptance from a specific group. Disinformation, in its turn, corresponds to false information that requires users not to follow the social rules for the dissemination of information, sharing false information. United Nations Educational, Scientific, and Cultural Organization also defined the term "malicious information", which was characterized by the element Ability and its sub-element "Social Deviance". This correspondence is due to the fact that "malicious information" is

Chart 3. Correlations of misinformation definitions and elements of the Fogg's Behavior Model.

\begin{tabular}{lll}
\hline Organizations & Elements of the Fogg's Behavior Model & Correlations: definitions and elements of the Fogg's Behavior Model \\
\hline Unesco & Motivation: Social Acceptance/Rejection & $\begin{array}{l}\text { This definition can be related to the element Motivation: Social Acceptance/ } \\
\text { Rejection, as it deals with the necessity of either informing or believing } \\
\text { something to be socially accepted, or failing to inform or believing in } \\
\text { something for fear of social rejection. }\end{array}$ \\
\hline \multirow{3}{*}{ Oxford Dictionary } & Ability: Social Deviance & $\begin{array}{l}\text { Misinformation's definition deals with informing or reporting something } \\
\text { wrong and it relates to the Social Deviance Ability element, as it requires going } \\
\text { against society's norms and rules. }\end{array}$
\end{tabular}

Source: Based on the study of Fogg (2009); Ireton; Posetti (2018); Oxford... (2020b).

Note: UNESCO: United Nations Educational, Scientific and Cultural Organization. 
considered to be true information used in a negative way, either because it was collected illegally or because it was disseminated as if it belonged to contexts or dates other than the original (Chart 4). Finally, the definition of PostTruth developed by the Oxford Dictionary includes false information that has sparks (Trigger: Spark) that increase its credibility and make people quickly believe in its veracity. It is also related with the "Pleasure/Pain" and "Hope/Fear" sub-elements (Motivation) characteristic in this definition, because it responds for individuals' emotional reactions when they encounter information that emotionally interferes with their ideologies and beliefs.

Chart 4. Correlations of the definitions of "misleading information" (Unesco) and "post-truth" (Oxford Dictionary) information and elements of the Fogg's Behavior Model.

\begin{tabular}{|c|c|c|}
\hline Organizations & Elements of the Fogg's Behavior Model & Correlations: definitions and elements of the Fogg's Behavior Model \\
\hline Unesco & Ability: Social Deviance & $\begin{array}{l}\text { This definition deals with true information that is stolen and spread, most } \\
\text { of the times illegally, with the purpose of harming a person or group. This } \\
\text { definition is related to element Ability: Social Deviance, that deals with } \\
\text { behavior that goes against the standards and rules in order to cause damage. }\end{array}$ \\
\hline \multirow[b]{2}{*}{ Oxford Dictionary } & Motivation: Pleasure/Pain and Hope/Fear & $\begin{array}{l}\text { This definition relates to the Hope/Fear and Pleasure/Pain from the Ability } \\
\text { element, as it involves people's feelings and beliefs, granting them superior } \\
\text { importance than of the facts. }\end{array}$ \\
\hline & Trigger: Spark & $\begin{array}{l}\text { Relating to Trigger: Spark, the definition acknowledges that when people } \\
\text { believe in certain things, they are more likely to believe information. Thus, } \\
\text { when a Spark of grand commotion arises regarding a certain subject, it } \\
\text { makes it more relevant for them and people respond to their feelings and } \\
\text { beliefs more than to the facts. }\end{array}$ \\
\hline
\end{tabular}

Source: Based on the study of Fogg (2009); Ireton; Posetti (2018); Oxford... (2020c).

Note: UNESCO: United Nations Educational, Scientific and Cultural Organization.

The correlation between the concepts and Fogg's elements evidences how the tools and mechanisms used by digital developers are linked with the characteristics of behavioral models that involve human feelings, individuals' ideologies, beliefs and prejudices. These factors are related to the dissemination of false information, mainly in digital environments that tend to cover the categories of Motivation, Ability and Trigger better.

The elements Ability and Motivation had nine occurrences each and Trigger had six occurrences. This means that, when related to the concepts of false information, the elements are characterized as motivational, emotional, and easy and simple to be used in publications by individuals. In Ability, the most present sub-element was Social Deviation (four occurrences), followed by the "Brain Cycles" and "Time" (two occurrences each). There was also one occurrence for the Money sub-element, and no occurrences for "Physical Effort" and "Non-Routine" behavior. This means that misinformation usually does not fail to follow social norms or rules, requiring little or no critical shortterm thinking and no financial expense to carry out a behavior involving false information. It also does not use "Physical Effort" and neither "Non-Routine" behavior. The first can be justified by the fact that false information is mainly set in digital environments, not requiring any physical effort in order to access it. In the second case, the same justification is used together with the fact that access to digital environments is currently routine for many people, and it is difficult to perform a behavior not routine in this environment.

Among the sub-elements of Motivation, the most representative is "Pleasure/Pain", with four occurrences, followed by three occurrences for "Social Acceptance/Rejection" and one occurrence for "Hope/Fear". This analysis states that the influence resulting in misinformation is dishonest and unethical, since it involves mostly the factor that Fogg considered unethical (Pleasure/Fear). Alternatively, the least present element (Hope/Fear) is the most ethical motivator to be used in an individual. Social Acceptance/Rejection also has a lot of occurrence, which means individuals will search for acceptance even if it means following untruthful actions. 
The most present sub-element among Triggers is the "Spark", with three occurrences, followed by the "Facilitator", with two occurrences, and the "Sign", with one occurrence. This shows that the most used trigger to influence a target behavior related to disinformation is the "Spark", that is, the trigger that leads to an increased motivation of an individual to perform a certain action.

In addition to formulating concepts and definitions about disinformation, Unesco and the European Commission have developed tools to use against the spread of false information. United Nations Educational, Scientific, and Cultural Organization believes that in order to combat disinformation, only content with proven veracity should be shared and critical thinking and question-asking are essential before publishing certain information (Ireton; Posetti, 2018). The European Commission developed a joint activity to combat misinformation in social media, which involves everyone from the creators of the platform to users (European Commission, 2019).

Other institutions that contribute to this achievement, but did not present a defined concept regarding disinformation are the International Federation of Library Associations and Institutions and FackCheck, a fact checker company that verifies whether the news or information are false, true, or satires. Both of them have ways of preventing the sharing disinformation, as well as of raising questions about author, source, description, date, and other characteristics of a publication. FackCheck developed a series of questions to be asked before sharing a publication (Kiely; Robertson, 2016), that was transformed into a booklet, which was later disseminated worldwide by the International Federation of Library Associations and Institutions (International..., 2020).

\section{Final Considerations}

False information, fake news, and misinformation are created and disseminated with the main purpose of manipulation. In this research, the data analysis showed that the definitions of terms related to false information have some correlations with the elements present in Fogg's Behavior Model, a model used by many digital companies to manipulate user behavior.

In order to stop false information, misinformation, fake news, among others, it is necessary to know how they are created and disseminated, the reasons they are developed and who can be harmed by them. It is also an important factor to identify why individuals share false information or news and how that information influences human behavior to the point that people disseminate something that is not true. These changes, whether in behavior or attitude influenced by other individuals, fit with the elements of Fogg's Behavior Model.

This research presents an analysis aimed to better understanding how misinformation occurs in relation to the persuaded behavior of citizens. It does so by correlating the selected definitions of disinformation (and related concepts) with the elements developed by Fogg to achieve desired behavior and treatment, as shown in Charts 1, 2, 3 and 4. In order to get a certain individual or group to behave as desired, according to the Fogg factors, it is necessary to use the maximum number of its elements - that is, the greater the number of factors, the easier the performance of a certain behavior. Thus, the definitions established by the Oxford Dictionary and the European Commission (six sub-elements) were those that showed the largest number of correlations with Fogg's Behavior Model. Right after come the definitions of the World Economic Forum, with five sub-elements, Unesco, with four, and Reuters with the smallest scale of correlation (two sub-elements).

The element with the greatest presence in the research was Motivation (eight occurrences), followed by Ability (nine occurrences), and Trigger (six occurrences). Within Motivation, the most present sub-element was Pleasure/Pain; in Ability, it was Social Deviation; and in Trigger, the sub-element with the highest correlation was Spark. These factors explain that when false information is posted with the intent to make people share the information without verification, it must be easily accessible and disseminated, in addition to offering motivation for the individual to share it. If neither of these two characteristics are in place, it should then present triggers that 
encourage people to disseminate false information. Thus, the elements of the Fogg's Behavior Model that most correlated with the definitions of the selected institutions and organizations was the Pleasure/Pain motivator, which seeks a quick and primitive response from the user. Most of the time, pieces of false information can go against social norms (an example of going against social norms is going to work in pajamas at a company that requires uniform), go against contrary to the Ability with more occurrences (Social Deviance) and these factors can cause damage to societies.

The definitions use Sparks as a form of Trigger. In that case, we do not need to be ready (or motivated) to share disinformation, as the Trigger will be aimed at creating the projected motivation by means of Pleasure/Pain impulses. The use of Fogg's Behavior Model can thus characterize the reasons leading individuals to perform certain actions, such as sharing disinformation on social media. For example, for a user of social media to share certain pieces of information or news (false or true) that reach him, it is necessary that this publication develops a motivational reaction in the individual, whether positive (such as happiness) or negative (like anger). It is also necessary that the publication is easily accessible, easy to read, and easy to share with others. Finally, it is important that the individual has an interest in the content presented in the information or news complementing the motivational and skill actions such as relating the published subject with beliefs and ideologies are related or not. All these elements make sharing fake publications easier and more likely to happen. Fogg's factors use of mechanism sin order to persuade behavior, which is correlated with factors, elements, and definitions of misinformation and false news. The correlations clarify how it is possible to use characteristics present in false information and how some people or organizations and institutions use these mechanisms to disseminate and disinformation to others.

The research aimed to contribute with the development of studies on false information, its dissemination on a large scale, and its relationship with human behavior in the field of Information Science and other areas. We expect to carry out future studies on the existing links between the dissemination of information, human behavior, and digital environments, in order to obtain efficient and effective mechanisms and tools to solve the growth and sharing of false information.

\section{Contributors}

E. MURIEL-TORRADO contributed in the conception, writing, and review of the article. D. B. PEREIRA contributed in the creation, data collection and analysis, and writing of the article.

\section{References}

Alcott, H.; Gentzkow, M. Social media and fake news in the 2016 election. Journal of Economic Perspectives, v. 31, n. 2, p. 211-236, 2017. Available from: https://www.nber.org/papers/. Access on: May 5, 2020.

Barreto, A. A. A questão da informação. São Paulo em Perspectiva, v. 8, n. 4, p. 3-8, 1994. Disponível em: http:// produtos.seade.gov.br/produtos/spp/v08n04/v08n04_01. pdf. Acesso em: 5 maio 2020.

Bauman, Z. Modernidade líquida. Rio de Janeiro: Zahar, 2001.

Borko, H. Information Science: what is it? American Documentation, v. 19, n. 1, p. 3-5, 1968.

Buckland, M. Information as thing. American Society of Information Science, v. 42, n. 5, p. 351-360, 1991.

Burke, P. Uma história social do conhecimento: de Gutenberg a Diderot. Rio de Janeiro: Zahar, 2003.
Capurro, R. Epistemologia e Ciência da Informação. In: Encontro Nacional de Pesquisa em Ciência da Informação, 5., 2003, Belo Horizonte. Anais eletrônicos [...]. Belo Horizonte: UFMG, 2003. Disponível em: http://www.capurro.de/ enancib_p.htm. Acesso em: 5 maio 02020.

Castells, M. A sociedade em rede. 7. ed. São Paulo: Paz e Terra, 2003.

Charlton, E. Fake news: what it is, and how to spot it. World Economic Forum, Mar. 6, 2019. Available from: https://www. weforum.org/agenda/2019/03/fake-news-what-it-is-andhow-to-spot-it/. Access on: May 5, 2020.

Cooke, N. A. Fake news and alternative facts: information literacy in a post-truth era. Chicago: ALA Editions, 2018.

D'Ancona, M. Pós-verdade: a nova guerra contra os fatos em tempos de fake news. São Paulo: Faro Editorial, 2018. 
European Commission. Tackling online disinformation. Sep. 13, 2019. Available from: https://ec.europa.eu/digital-singlemarket/en/tackling-online-disinformation. Access on: May 5, 2020.

Fogg, B. J. A behavior model for persuasive design. In: International Conference on Persuasive Technology, 4., California. Proceeding Online [...]. California: ACM, 2009. Available from: https://dl.acm.org/doi/10.1145/1541948.154 1999. Access on: May 5, 2020.

International Federation of Library Associations and Institutions. How to spot fake news? Mar. 16, 2020. Available from: https://www.ifla.org/publications/node/11174. Access on: May 5, 2020.

Ireton, C.; Posetti, J. (ed.). Journalism, 'fake news' and disinformation: a handbook for journalism education and training. Paris: Unesco, 2018. Available from: https://en.unesco. org/fightfakenews. Access on: May 5, 2020.

Kiely, E.; Robertson, L. How to spot fake news? FactCheck, Nov. 18, 2016. Available from: https://www.factcheck.org/2016/11/ how-to-spot-fake-news/. Access on: May 5, 2020.

Leite, L. R. T.; Matos, J. C. Zumbificação da informação: a desinformação e o caos informacional. Revista Brasileira de Biblioteconomia e Documentação, v. 13, p. 2334-2349, 2017.

Masi, D. Uma simples revolução: trabalho, ócio e criatividade: novos rumos para uma sociedade perdida. Rio de Janeiro: Sextante, 2019.

Moutinho, K.; Roazzi, A. As teorias da ação racional e da ação planejada: relações entre intenções e comportamentos. Avaliação Psicológica, v. 9, n. 2, p. 279-287, 2010. Disponível em: http://pepsic.bvsalud.org/scielo.php?script=sci_arttext\& pid=S1677-04712010000200012. Acesso em: 5 maio 2020.

Neves, D. A. Ciência da informação e cognição humana: uma abordagem do processamento da informação. Ciência da Informação, v. 35, n. 1, p. 39-44, 2006. Doi: https://doi. org/10.1590/S0100-19652006000100005.

Nielsen, R. K.; Graves, L. "News you don't believe": audience perspectives on fake news. Reuters Institute, v. 3, p. 1-8, 2017. Available from: https://reutersinstitute.politics.ox.ac.uk/sites/ default/files/2017-10/Nielsen\&Graves_factsheet_1710v3_ FINAL_download.pdf. Access on: May 5, 2020.

Oxford Advanced Learner's Dictionary. Definition of fake news noun. Oxônia: Oxford University Press, 2020a. Available from: https://www.oxfordlearnersdictionaries.com/us/definition/ english/fake-news?q=fake+news. Access on: May 5, 2020.

Oxford Advanced Learner's Dictionary. Definition of misinformation noun. Oxônia: Oxford University Press, 2020b. Available from: https://www.oxfordlearnersdictionaries.com/ us/definition/english/misinformation?q=misinformation. Access on: May 5, 2020.

Oxford Advanced Learner's Dictionary. Definition of post-truth adjective. Oxônia: Oxford University Press, 2020c. Available from: https://www.oxfordlearnersdictionaries.com/us/definition/ english/post-truth?q=Post-truth. Access on: May 5, 2020.

Rodrigues, A. Psicologia social para principiantes: estudo da interação humana. 13. ed. Rio de Janeiro: Editora Vozes, 2011.

Silva, C. G. C. O bolsonarismo da esfera pública: uma análise Foucaultiana sobre os conceitos de pós-verdade, fake news e discurso de ódio presentes nas falas de Bolsonaro. 2020. Dissertação (Mestrado em Letras) - Universidade Federal do Amazonas, Manaus, 2020.

United Nations Educational, Scientific and Cultural Organization. O que são as "notícias falsas"? Brasília: Unesco, 2019. Disponível em: http://www.unesco.org/new/fileadmin/ MULTIMEDIA/FIELD/Brasilia/pdf/brz_ci_what_are_faknews_ por_2019_01.pdf. Acesso em: 5 maio 2020.

Yuexiao, Z. Definitions and sciences of information. Information Processing and Management, v. 24, n. 4, p. 479-491, 1988. Doi: https://doi.org/10.1016/0306-4573(88)90050-7. 